\title{
Earnings Informativeness And Ownership Structure In Japan
}

Wikil Kwak, University of Nebraska at Omaha, USA

Jack Armitage, University of Nebraska at Omaha, USA

\begin{abstract}
This paper investigates the association between institutional ownership structures and the quality of earnings information via changes in earnings response coefficients for a sample of Japanese firms during 1990-1998. From these results we can predict that the greater the percentage of institutional shareholders in Japan, the better the quality of earnings information and the higher the foreign ownership; the quality of earnings information is better during Japan's recession period of 1990-1998. However, keiretsu membership percentage is not important for the quality of earnings information in Japan even though firm size, leverage ratio, and growth are important factors in earnings information in Japan.
\end{abstract}

Keywords: institutional ownership, quality of earnings information, earnings response coefficient, foreign ownership

Data Availability: All data are available from public sources.

\section{INTRODUCTION}

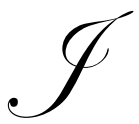

apan is a unique country in terms of business and capital market practices. After the stock market crash of 1991, the Japanese capital market claimed to follow the western model and their banking and accounting rules followed those of OECD countries. However, there are still some major differences such as keiretsu, main bank, direct involvement of owners and founders, and foreign ownership structures. Some of these corporate governance structures in Japan are thought of as useful mechanisms to diversify business risks and are followed by other Asian countries such as South Korean chaebol or business groups. However, the Samsung group is now being accused of reserving huge amounts of private funds for the Lee family's personal use and, as of today, the government is starting to investigate those funds.

The purpose of this paper is to exam these institutional ownership structures in Japan, which contributed to corporate governance after the market crash of 1991. The first unique structure of corporate governance in Japan is a 'keiretsu' system. Based on prior studies, corporate governance issues had two conflicting theories. Jensen and Meckling (1976) propose higher convergence of interests of ownership and managers while Stultz (1988) proposes less convergence of managerial ownership and owners' interests. However, it is an empirical question to be tested. In addition, Johnston (1995) suggests Japanese managers have non-myopic strategies and policies. However, all of these assertions may change after the market crash. This paper tests empirically the quality of earnings information via the earning response coefficient (ERC) measure using Japanese data after the market crash. Our paper is organized as follows: the next section reviews the background and develops hypotheses, the third section discusses research methodology, and the last section presents findings and conclusions.

\section{BACKGROUND AND HYPOTHESES DEVELOPMENT}

Keiretsu or business grouping is a unique system in Japan. Chaebols in South Korea or business groups in Hong Kong or China are close examples among Asian countries. By cross-sharing vertically by product suppliers or distributors or cross-sharing horizontally financially, they assume to diversify business risk or share information 
within keiretsu firms. This system will protect interests of managers or owners within groups, but from outside investors' points of views, the keiretsu firm's financial information may not be easy to interpret or understand. Prowse (1992) cannot find any significant relationship between keiretsu firms and independent firm performances using 1984 Japanese data. In addition, Jameson et al. (2000) find that keiretsu firms are less effective at shareholder wealth maximization either in horizontal or vertical keiretsu firms using 1985-1989 data. However, Ferris et al. (1995) find that keiretsu firms are more effective in controlling conflicts of interests under the agency context using 1990 Japanese data. Since there are mixed results in previous studies, it warrants testing using more current data. In addition, we measure the issue as the quality of earnings information for investors using the earnings response coefficient. Therefore, our first hypothesis in an alternative form is as follows:

H1: Ceteris paribus, the quality of earnings information is higher for keiretsu firms compared with non-keiretsu firms.

Usually, there is a main bank within the keiretsu firms and the main bank acts as the monitoring and control agent in the Japanese capital market. The main bank system shares information between the bank and the firm. In the Japanese system, the main bank and other financial institutions incorporate a voluntary disclosure mechanism on the part of managers (Sheard, 1989). Gedajlovic et al. (2003) find empirically that financial institutions in Japan act as effective monitors using 1986-1991 data. However, Morck and Nakamura (1999) find that banks' and other financial institutions' monitoring is not perfect using 383 manufacturing firms during 1981-87. They propose that bankers appointed to firms' boards after poor performances appear to be a response to poor liquidity issues. Morck et al. (2000) propose that Japanese financial institutions are also equity holders and takeovers are rare in Japan. They also find that managerial ownership and firm value is positive in Japan. Hoshi et al. (1990) propose a similar view that main banks and other insurance companies hold a majority of debt and equities in Japan. They share information between firm and creditors. Therefore, even though Japanese firms have higher debt ratios, they do not show a negative relation between leverage ratios and conflicts of interests between shareholders and debt-holders (Prowse, 1990). Prior to 1990, the two largest institutional shareholders in Japan were banks and life insurance companies. However, this may change after the market crash. Jennings (2005) posits that institutional investors are key information collectors, and usually large enough to influence managers' strategic decisions, but they may be myopic, have a lack of expertise, and have agency problems. Sandra et al. (2001) test the quality of earnings information and level of institutional holdings and find that there is a positive relationship between institutional holdings and earnings information, but their data is from 1995. We aggregated financial institutions due to our data limitations and this may be more appropriate in Japanese studies as they may have cross-sharings, as they did in Pushner's (1995) study. Therefore, our second hypothesis in an alternative form is as follows:

H2: Ceteris paribus, there is a positive relationship between institutional ownership and the quality of earnings information in Japanese firms.

Foreign investors in Japanese firms may have different motivations than domestic institutional investors. Hiraki et al. (2003) find that foreign investors in Japan are more export-oriented. In other words, foreign investors allocate more investments to familiar firms. Ferris and Park (2005) find similar results that foreign investors allocate their funds in well-performing firms. Jiang and Kim (2004) posit that foreign investors prefer equity shares of firms with low information asymmetry and find that foreign institutional investors in Japan from 1976 to 1994 are investing more in low information asymmetry firms. Similarly, Chung and Lee (1998) find that foreign investors trade more on current information and react more on earnings announcements. Based on previous conjectures we developed the third hypothesis in an alternative form as follows:

H3: Ceteris paribus, there is a positive relationship between foreign ownership and the quality of earnings information in Japanese firms.

Previous studies in this context of earnings quality and ownership structures used size, risk, debt, growth, and persistence as control variables (see Jung and Kwon, 2002, for an example). Watts and Zimmerman (1990) posit that large corporations are more politically sensitive than smaller firms. Jensen et al. (1992) also use size, risk, the number of divisions, and research and development expenditures in their study. The Japanese use large business 
groups and trading partners to spread over risk factors (Fitzgerald, 2000). Therefore, risk should be controlled. In addition, in Japan, large debt holders are also large equity holders and their equity trading is not active (Pushner, 1995). Therefore, the debt or leverage ratios should be controlled. The Japanese usually emphasize growth in sales and market share rather than earnings and growth controlled in a similar study (Hermann et al., 2003). Earnings persistence may be different in Japan compared with the U.S. (Hermann et al., 2000). Therefore, we control growth and persistence in our study. With all control variables, our model is as follows:

$$
\begin{aligned}
\mathrm{R}_{i}= & \mathrm{b}_{0}+\mathrm{b}_{1} \mathrm{E}_{i} / \mathrm{P}_{i t-1}+\mathrm{b}_{2} \text { INST }_{i} \times \mathrm{E}_{i} / \mathrm{P}_{i t-1}+\mathrm{b}_{3} \text { KEIRETSU }_{i} \times \mathrm{E}_{i} / \mathrm{P}_{i t-1}+\mathrm{b}_{4} \text { FOREIGN }_{i} \times E_{i} / \mathrm{P}_{i t-1}+\mathrm{b}_{5} \text { SIZE }_{i t}+ \\
& \mathrm{b}_{6} \text { RISK }_{i t}+\mathrm{b}_{7} \text { DEBT }_{i t}+\mathrm{b}_{8} \text { GROWTH }_{i t}+\mathrm{b}_{9} \text { PERSIST }_{i t}+\mathrm{b}_{10} \mathrm{YEAR}_{i t}+e_{i}
\end{aligned}
$$

where $\mathrm{R}_{i}=$ stock return of firm $i$ for the 12-month period to the year-end, calculated as $\left(\mathrm{P}_{i t}-\mathrm{P}_{i t-1}+\mathrm{D}_{i t}\right) / \mathrm{P}_{i t-1} . \mathrm{P}_{i t}$ is the stock price of firm $i$ at $t$ and $\mathrm{D}_{i t}$ is the dividend of firm $i$ at $t$ : $\mathrm{E}_{i}=$ earnings per share before extraordinary item of firm $i$; INST $_{i}=$ top five institutional owners in Japan Company Handbook (JCH) including main banks and insurance companies; KEIRETSU $_{i}=$ keiretsu firms vs. non-keiretsu firms as a dummy variable; FOREIGN ${ }_{i}=$ foreign ownership in percent; $\mathrm{SIZE}_{i}=$ firm size calculated using logarithm of total sales; RISK $_{i}=$ risk of the firm using market beta; $\mathrm{DEBT}_{i}=$ leverage ratio calculated as total debt divided by total assets; GROWTH $_{i}=$ growth measured by market value of equity divided by book value of equity; $\operatorname{PERSIST}_{i}=$ persistence of earnings calculated by the autocorrelation of earnings during 1990-1998; and $\mathrm{YEAR}_{i}=$ year dummy variable during the test period.

\section{SAMPLE AND DATA DESCRIPTIONS}

The original sample consists of all March 31 fiscal year-end Japanese firms that are included in the 2000 PACAP database of Japan compiled by the Pacific-Basin Capital Market (PACAP) Research Center at the University of Rhode Island. From these firms, we exclude firms whose ownership data are unavailable from the $\mathrm{JCH}$ and whose financial and stock return data are missing from the PACAP database. Keiretsu classification is used as an indicator variable representing the presence of inter-keiretsu ownership held by the other institutions within the keiretsu if the sample firm belonged to one of six keiretsu groups. The big six groups include the Mitsui, Mitsubishi, Sumitomo, Fuyo, Sanwa, and Dai-Ichi Kangyo (Miyashita and Russell, 1994). Foreign ownership (FOREIGN) is measured by the percentage of ownership held by foreign institutional shareholders. We end up with a total of 9,560 firm-year observations. The lowest number of firm-year observations was 1,008 in 1990 and the highest number was 1,089 in 1997.

\section{RESULTS}

Table 1, Panel A reports distribution of ownership percentage by relevant owners. Foreign ownership in Japan was $4.65 \%$ in 1990 , but it was $8.13 \%$ in 1998 . During this test period, foreign ownership percentages increased each year. Institutional ownership percentage of the top five major shareholders from JCH was $16.03 \%$ in 1990, but it was $14.93 \%$ in 1998 . This ratio decreased over time through 1998 . Keiretsu ownership percentage shows the proportion of keiretsu firms analyzed in our study; it was 15\% in 1990, but only 13\% in 1998. During this time, the Japanese capital market appears to follow the western capital market model.

Table 1, Panel B presents mean, median, and standard error of ownership percentage. The average (median) value of foreign ownership was $6.05 \%$ (3.50\%), top five institutional ownership was $15.12 \%$ (14.80\%), and keiretsu ownership was $0.14 \%(0.00 \%)$. We examined the Person correlation of our study variables and EP and EP x FOREIGN are 0.4884 and SIZE and EP x KEIRETSU are 0.3403 . Other variables are not highly correlated and not reported here. 
Table 1

Panel A: Distribution of ownership percentage by relevant owners

\begin{tabular}{|c|c|c|c|c|}
\hline & Foreign ownership & Institutional ownership & Keiretsu ownership* & Number of observations \\
\hline $\mathbf{1 9 9 0}$ & 4.65 & 16.03 & 0.15 & 1008 \\
\hline $\mathbf{1 9 9 1}$ & 4.29 & 15.39 & 0.14 & 1035 \\
\hline $\mathbf{1 9 9 2}$ & 4.77 & 14.64 & 0.14 & 1065 \\
\hline $\mathbf{1 9 9 3}$ & 5.06 & 15.43 & 0.14 & 1073 \\
\hline $\mathbf{1 9 9 4}$ & 5.32 & 15.40 & 0.13 & 1079 \\
\hline $\mathbf{1 9 9 5}$ & 6.38 & 15.08 & 0.13 & 1077 \\
\hline $\mathbf{1 9 9 6}$ & 7.07 & 14.95 & 0.13 & 1077 \\
\hline $\mathbf{1 9 9 7}$ & 8.16 & 14.52 & 0.13 & 1089 \\
\hline $\mathbf{1 9 9 8}$ & 8.13 & 14.93 & 0.13 & 1057 \\
\hline Total & & & & 9560 \\
\hline
\end{tabular}

*: the proportion of keiretsu firms analyzed

Panel B: Descriptive statistics of ownership by relevant owners

\begin{tabular}{|l|r|c|c|c|c|c|}
\hline \multicolumn{1}{|c|}{ Variable } & Mean & Median & Std Error & Minimum & Maximum & N \\
\hline Foreign ownership & 6.05 & 3.50 & 0.08 & 0.00 & 77.80 & 9560 \\
\hline Institutional ownership & 15.12 & 14.80 & 0.08 & 0.20 & 343.00 & 9560 \\
\hline Keiretsu ownership & 0.14 & 0.00 & 0.00 & 0.00 & 1.00 & 9560 \\
\hline
\end{tabular}

Table 2 reports overall firm stock returns on distinct interaction terms. EP is positive and significant at the $1 \%$ significance level. This shows that earnings have significant relations with stock returns. Our model is significant with adjusted $\mathrm{R}^{2}$ value of $35.89 \%$. The Wald Chi-square test is also performed since keiretsu ownership variable use 0 and 1 dichotomous value and median value was 0 as reported in Table 1 , Panel $\mathrm{B}$, but the overall model is significant. EP $\mathrm{x}$ INST is positive and significant. This suggests that the greater the percentage of holdings of institutional shareholders, the more informative the earnings. EP x FOREIGN is also positive and significant. This shows that foreign shareholders in Japan during their recession period have a positive influence on earnings information. However, EP x KEIRETSU is positive, but marginally significant. This result indicates that keiretsu membership has a marginal impact on earnings information. The year dummy variable is included and each year is significant at the $1 \%$ level.

Table 2: Regression of stock returns on distinct interaction terms

\begin{tabular}{|c|c|c|}
\hline & Coefficients & t-value \\
\hline EP & 0.6647 & $17.71 * * *$ \\
\hline EP×INST & 0.1799 & $2.73 * * *$ \\
\hline EP×KEIRETSU & 0.1472 & $1.89 *$ \\
\hline EP×FOREIGN & 0.4849 & $8.79 * * *$ \\
\hline INTERCEPT & -0.2044 & $-39.85 * * *$ \\
\hline $\begin{array}{l}\text { YEAR } \\
\text { DUMMIES* } \\
\text { (1991-1998) }\end{array}$ & Included & - \\
\hline Adj-R ${ }^{2}$ & \multicolumn{2}{|c|}{0.3589} \\
\hline Wald Chisq & \multicolumn{2}{|c|}{$10204.61 * * *$} \\
\hline $\mathbf{N}$ & \multicolumn{2}{|c|}{9560} \\
\hline $\begin{array}{l}\text { Model: Cross-sect } \\
*: \text { Year } 1990 \text { is ex } \\
* * *: \text { the } 1 \% \text { of sig } \\
* *: \text { the } 5 \% \text { of sig } \\
* \quad \text { : the } 10 \% \text { of sig }\end{array}$ & $\begin{array}{l}\text { sion with heter } \\
\text { or dummy varia }\end{array}$ & ero and not \\
\hline
\end{tabular}


Collins et al. (1999) report that if earnings are negative, the quality of earnings information may not be the same. Therefore, we split our sample into a positive EP group and negative EP group and the results are reported in Table 3. We lose some data points because of the extreme value of EP in this process. When EP is positive our results are consistent with the results in Table 2. Even the EP x KEIRETSU variable is significant at the 5\% level. However, when EP is negative, the EP x INST variable is not significant. The EP x KEIRETSU variable is negative and significant. This result implies that when earnings are negative, the greater percentage of keiretsu membership of owners, the less the quality of earnings information. The models are still significant when either EP is positive (adjusted $\mathrm{R}^{2}$ of $39.90 \%$ ) or EP is negative (adjusted $\mathrm{R}^{2}$ of $32.98 \%$ ).

Table 3: Regression of stock returns on distinct interaction term by EP size

\begin{tabular}{|c|c|c|c|c|}
\hline & \multicolumn{2}{|c|}{$E P>=0$} & \multicolumn{2}{|c|}{ EP $<0$} \\
\hline & Coeff. & t-value & Coeff. & t-value \\
\hline EP & 0.8494 & $16.36 * * *$ & -0.0127 & -0.18 \\
\hline EP×INST & 0.1453 & $2.09 * *$ & 0.0202 & 1.26 \\
\hline EP×KEIRETSU & 0.1728 & $2.17 * *$ & -1.2898 & $-3.49 * * *$ \\
\hline EP×FOREIGN & 0.4276 & $7.32 * * *$ & 0.0389 & $2.45 * *$ \\
\hline INTERCEPT & -0.2084 & $-40.80 * * *$ & -0.2274 & $-13.70 * * *$ \\
\hline $\begin{array}{l}\text { YEAR DUMMIES* } \\
\text { (1991-1998) }\end{array}$ & Included & & Included & \\
\hline Adj-R ${ }^{2}$ & \multicolumn{2}{|c|}{0.3990} & \multicolumn{2}{|c|}{0.3298} \\
\hline Wald Chisq & \multicolumn{2}{|c|}{$9638.12 * * *$} & \multicolumn{2}{|c|}{$5790.18^{* * *}$} \\
\hline $\mathbf{N}$ & \multicolumn{2}{|c|}{8729} & \multicolumn{2}{|c|}{812} \\
\hline \multicolumn{5}{|c|}{$\begin{array}{l}\text { Model: Cross-sectional time-series FGLS regression with heteroskedasticity and AR(1) Correction } \\
\text { *: Year } 1990 \text { is excluded as base year. Each year dummy variable is significantly different from zero and not reported here. } \\
\text { However, when EP < 0, } 1998 \text { is not significant. }\end{array}$} \\
\hline
\end{tabular}

Table 4 presents full sample regression of stock returns with total control variables. The model is significant with adjusted $\mathrm{R}^{2}$ of $37.64 \%$ (Wald Chi-square test of 11707.95). EP is significant and positive as expected. EP $\mathrm{x}$ INST is positive and significant at the 5\% level. Therefore, we reject the $\mathrm{H} 2$ null hypothesis. This result indicates that the greater institutional shareholders in Japan, the better the quality of earnings information. EP $x$ FOREIGN is positive and significant at the $1 \%$ level. Thus, we reject the $\mathrm{H} 3$ null hypothesis. This result shows that the higher the foreign ownership in Japan, the better the quality of earnings information. Ferris and Park (2005) find similar results. However, EP x KEIRETSU is not significant. Therefore, we cannot reject the H1 null hypothesis. This result shows that keiretsu membership percentage and the quality of earnings information are not related. Prowse (1992) finds similar results using earlier data. SIZE is positive and significant. It is interesting that earnings are more informative as the firm size increases in Japan. Japanese firms may focus on their long-term reputations rather than short-term earnings. DEBT is negative and significant. The higher the leverage ratios, the less informative earnings are informative in Japan. GROWTH is positive and significant as expected. However, RISK and PERSIST are negative and not significant in Japan. 
Table 4: Regression of stock returns on full regressors

\begin{tabular}{|c|c|c|}
\hline & Coefficients & t-value \\
\hline EP & 0.7340 & $20.17 * * *$ \\
\hline EP×INST & 0.1309 & $2.11 * *$ \\
\hline EP×KEIRETSU & 0.1076 & 1.40 \\
\hline EP×FOREIGN & 0.1851 & $3.39 * * *$ \\
\hline SIZE & 0.0211 & $15.99 * * *$ \\
\hline RISK & $-3.83 e-06$ & -1.48 \\
\hline DEBT & -0.2187 & $-24.88 * * *$ \\
\hline GROWTH & 0.0000169 & $20.10 * * *$ \\
\hline PERSIST & -0.0047 & -0.41 \\
\hline INTERCEPT & -0.3739 & $-23.61 * * *$ \\
\hline $\begin{array}{l}\text { YEAR DUMMIES* } \\
(1991-1998)\end{array}$ & Included & - \\
\hline Adj-R ${ }^{2}$ & \multicolumn{2}{|c|}{$\frac{1}{0.3764}$} \\
\hline Wald Chisq & \multicolumn{2}{|c|}{$11707.95 * * *$} \\
\hline $\mathbf{N}$ & \multicolumn{2}{|c|}{9560} \\
\hline \multicolumn{3}{|c|}{$\begin{array}{l}\text { Model: Cross-sectional time-series FGLS regression with heteroskedasticity and AR(1) Correction } \\
*: \text { Year } 1990 \text { is excluded as base year. Each year dummy variable is significantly different from zero and not reported here. } \\
* * *: \text { the } 1 \% \text { of significance level } \\
* *: \text { the } 5 \% \text { of significance level } \\
*: \text { : the } 10 \% \text { of significance level. }\end{array}$} \\
\hline
\end{tabular}

Table 5 reports the full regression with all control variables by EP size. When EP is positive, only EP $\mathrm{x}$ KEIRETSU is marginally significant. However, SIZE, DEBT, GROWTH, PERSIST are significant. In 1996, the model is not significant. When EP is negative, EP x KEIRETUS is negative and marginally significant. EP $\mathrm{x}$ FOREIGN is positive and significant. DEBT, GROWTH, and PERSIST are significant. Again in 1998, the model is not significant.

Table 5: Regression of stock returns on full regressors by EP size

\begin{tabular}{|c|c|c|c|c|}
\hline & \multicolumn{2}{|c|}{$E P>=0$} & \multicolumn{2}{|c|}{ EP $<0$} \\
\hline & Coeff. & t-value & Coeff. & t-value \\
\hline EP & 1.3309 & $24.87 * * *$ & -0.0488 & -0.68 \\
\hline EP×INST & 0.0774 & 1.19 & 0.1649 & 0.96 \\
\hline EP×KEIRETSU & 0.1319 & $1.65 *$ & -0.6151 & $-1.87 *$ \\
\hline EP×FOREIGN & -0.0473 & -0.81 & 0.5853 & $3.58 * * *$ \\
\hline SIZE & 0.0242 & $17.00 * * *$ & -0.0002 & -0.06 \\
\hline RISK & 0.0000 & -0.37 & 0.0000 & -1.35 \\
\hline DEBT & -0.3035 & $-29.85 * * *$ & -0.0891 & $-4.59 * * *$ \\
\hline GROWTH & 0.0000 & $28.24 * * *$ & 0.0000 & $3.82 * * *$ \\
\hline PERSIST & -0.0303 & $-2.53 * *$ & 0.1150 & $4.74 * * *$ \\
\hline INTERCEPT & -0.4486 & $-26.09 * * *$ & -0.1583 & $-3.44 * * *$ \\
\hline $\begin{array}{l}\text { YEAR DUMMIES* } \\
(1991-1998)\end{array}$ & Included & & Included & \\
\hline Adj-R ${ }^{2}$ & & & & \\
\hline Wald Chisq & & & & \\
\hline $\mathbf{N}$ & & & & \\
\hline \multicolumn{5}{|c|}{$\begin{array}{l}\text { Model: Cross-sectional time-series FGLS regression with heteroskedasticity and AR(1) Correction } \\
\text { *: Year } 1990 \text { is excluded as base year. Each year dummy variable is significantly different from zero and not reported here. } \\
\quad \text { However, when EP >=0, } 1996 \text { is not significant whereas } 1998 \text { is not significant when EP }<0 \text {. } \\
\text { ***: the } 1 \% \text { of significance level } \\
* *: \text { the } 5 \% \text { of significance level } \\
*: \text { the } 10 \% \text { of significance level. }\end{array}$} \\
\hline
\end{tabular}




\section{SUMMARY AND CONCLUSIONS}

This study tested empirically the relationship between the quality of earnings and ownership structure in Japan. From the results of distinct interaction terms, all variables are significant except EP x KEIRETSU is marginally significant. However, when EP is negative, EP x INST is not significant. When we include all control variables with the full sample, EP x KEIRETSU is not significant. This finding is consistent with previous studies such as Prowse (1992). In addition, RISK and PERSIST are not significant. If we divide this by EP size with full control variables, the results are not consistent. Only DEBT, GROWTH, and PERSIST are significant. From the overall sample with full control variable results, EP x INST and EP x FOREIGN are positive and significant. From these results we can predict that the greater the percentage of top five institutional shareholders in Japan, the better the quality of earnings information and the higher the foreign ownership, the quality of earnings information is better during their recession period of 1990-1998. However, keiretsu membership percentage is not important for the quality of earnings information in Japan even though, firm size, leverage ratio, and growth are important factors in earnings information in Japan.

The limitation of our study is that we used a small portion of the test period and cannot extend our findings into another time period. When EP is negative, the sample size is small and the results are not stable. However, we try to understand the quality of earnings information in Japan during their recessionary period after the market crash and after their real estate value declined significantly. This may help us to understand the U.S. situation we are facing from the sub-prime mortgage crisis.

\section{AUTHOR INFORMATION}

Wikil Kwak is a Professor and holds the William Hockett Alumni Association Diamond Professorship of Accounting at the University of Nebraska at Omaha. He received his Ph.D. in Accounting from the University of Nebraska in Lincoln. Dr. Kwak's research interests include the areas of Japanese capital market studies and mathematical programming approaches in data mining, capital budgeting, transfer pricing, performance evaluation. He has been published in the Contemporary Accounting Research, Abacus, the Engineering Economist, Review of Quantitative Finance and Accounting, Management Accountant, Journal of Petroleum Accounting and Financial Management, Multinational Business Review, Business Intelligence and Data Mining.

Jack Armitage is the Union Pacific Professor and Chair of the Department of Accounting at the University of Nebraska at Omaha. Dr. Armitage teaches accounting at both the undergraduate and graduate levels with his primary teaching areas in auditing and governmental accounting. His primary research areas are auditing and accounting education and he has published over 25 articles in academic and professional accounting journals. Dr. Armitage has significant experience working with academicians and practitioners outside the USA. He taught classes at foreign universities, consulted on curriculum, participated in roundtables for practicing auditors and accountants, and conducted research in foreign countries.

\section{REFERENCES}

1. Chung, D. Y., and J. Lee, Ownership Structure and Trading Volume Reaction to Earnings Announcements: Evidence from Japan. Pacific-Basin Finance Journal 6, 45-60, 1998.

2. Collins, D., M. Pincus, M. and H. Xie, Equity Valuation and Negative Earnings: the Role of Book Value of Equity, Accounting Review, 29-62, 1999.

3. Ferris, S. P., R. Kumar, and A. Sarin, The Role of Corporate Groupings in Controlling Agency Conflicts: The Case of Keiretsu, Pacific-Basin Finance Journal 3, 319-335, 1995.

4. Ferris, S. P. and K. Park, Foreign Ownership and Firm Value: Evidence from Japan, Advances in Financial Economics 11, 1-29, 2005.

5. Fitzgerald, R., Introduction: Asian Business Systems and Economic Development - Trade, Finance and Industrialization, Asia Pacific Business Review 7, 2, 1-16, 2000.

6. Gedajlovic E., D. M. Shapiro, and B. Buduru, Financial Ownership, Diversification and Firm Profitability in Japan, Journal of Management and Governance 7, 315-335, 2003. 
7. Hermann, D., T. Inoue, and W.B. Thomas, The Persistence and Forecast Accuracy of Earnings

Components in the USA and Japan, Journal of International Financial Management and Accounting 11, 1, 48-70, 2000.

8. Hermann, D., T. Inoue, and W.B. Thomas, The Sale of Assets to Manage Earnings in Japan, Journal of Accounting Research 4, 1, 89-108, 2003.

9. Hiraki, T., A. Ito and F. Kuroki, Investor Familiarity and Home Bias: Japanese Evidence, Asia-Pacific Financial Markets 10, 281-300, 2003.

10. Hoshi, T., A. Kashyap, and D. Scharfstein, The Role of Banks in Reducing Costs of Financial Distress in Japan, Journal of Financial Economics 27, 67-88, 1990.

11. Jameson, M., M. J. Sullivan, and R. L. Constand, Ownership Structure and Performance of Japanese Firms: Horizontal Keiretsu, Vertical Keiretsu, and Independents, Review of Pacific Basin Financial Markets and Policies 3, 4, 535-556, 2000.

12. Jennings, W. W., Further Evidence on Institutional Ownership and Corporate Value, Advances in Financial Economics 11, 167-207, 2005.

13. Jensen, G. R., D. P. Solberg, and T. S. Zorn, Simultaneous Determination of Insider Ownership, Debt, and Dividend Policies, Journal of Financial and Quantitative Analysis, 27, 2, 247-263, 1992.

14. Jensen, M. C. and W. H. Meckling, Theory of the Firm: Managerial Behavior, Agency Costs and Ownership Structure, Journal of Financial Economics, 305-360, 1976.

15. Jiang, Li and J. Kim, Foreign Equity Ownership and Information Asymmetry: Evidence from Japan, Journal of International Financial Management and Accounting 15, 3, 185-211, 2004.

16. Johnston, Stewart, Managerial Dominance of Japan's Major Corporations, Journal of Management 21, 2,191-209, 1995.

17. Jung, K. and S. Y. Kwon, Ownership Structure and Earnings In formativeness: Evidence from Korea, The International Journal of Accounting 37, 301-325, 2002.

18. Miyashita, K. and D. Russell, Keiretsu: Inside the Hidden Japanese Conglomerates. McGraw-Hill, Inc. New York, NY, 1994.

19. Morck R. and M. Nakamura, Banks and Corporate Control in Japan, The Journal of Finance 1, 319-339, 1999.

20. Morck R., M. Nakamura, and A. Shivdasani, Banks, Ownership Structure, and Firm Value in Japan, Journal of Business 73, 4, 539-567, 2000.

21. Prowse, S. D., Institutional Investment Patterns and Corporate Financial Behavior in the United States and Japan, Journal of Financial Economics 27, 43-66, 1990.

22. Prowse, S. D. The Structure of Corporate Ownership in Japan, The Journal of Finance 3, $1121-1140,1992$.

23. Pushner, G. M., Equity Ownership Structure, Leverage, and Productivity: Empirical Evidence from Japan, Pacific-Basin Finance Journal 3, 241-255, 1995.

24. Sandra, W. M., H. L. Jiang, and J. Kim, Shareholdings by Financial Institutions, Information Asymmetry and the Intertemporal Return-Earnings Relation in Japan, Asia-Pacific Financial Markets 8, 119-135, 2001.

25. Sheard, P., The Main Bank System and Corporate Monitoring and Control in Japan, Journal of Economic Behavior and Organization 11, 399-422, 1989.

26. The Japan Company Handbook, Toyo Keizai, Tokyo, 1990-1998.

27. Watts, R. L. and J. L. Zimmerman, Positive Accounting Theory: A ten Year Perspective, Accounting Review 65, 131-156, 1990. 